\title{
German biotech lab in bid to silence critic
}

Munich

A long-running dispute over freedom of speech at the Institute of Molecular Biotechnology (IMB) in Jena, eastern Germany, has flared up again following a move to stop the former deputy director from publicly criticizing the institute's current research.

Günter Löber published an article in the May issue of Laborjournal, a science news magazine, criticizing what he claimed was the low level of the institute's scientific output. Löber, an east German scientist, helped to develop the IMB's scientific mission when it was recreated in 1992 from an institute of the former East German Academy of Sciences.

The article also argued that the institute's scientific and administrative directors had blocked attempts to develop cutting-edge research in the so-called field of 'evolutionary biotechnology' which had been central to the institute's original mission.

To avoid being taken to court for breaking his obligation to maintain silence about institute affairs after retirement, Löber has now signed an agreement promising not to make further public criticisms of the IMB, against a penalty of DM50,000 (US\$26,450).

But the institute's move has raised concern among scientists, who feel that freedom of speech is being curtailed. "We should be able to say what we feel is true," says the Nobel prizewinning chemist Manfred Eigen,

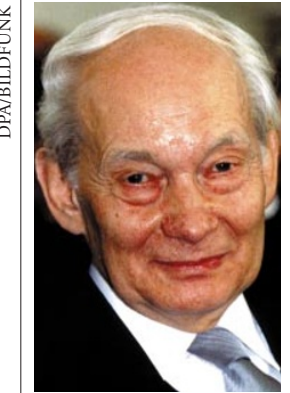

Eigen: 'don't try to gag retired scientists' nue, says Rolf Hilgenfeld, the institute's current scientific director, but at a lower level than originally envisaged. A new position of department head was advertised this summer.

Hebelieves the 'evolutionarybiotechnology' approach to drug design to be risky, however, preferring to give greater weight to the more "careful approach" of examining single specified genes as potential drug targets.

But Eigen and Löber claim that the institute's research is becoming mundane, contrary to political aspirations to make research institutes founded in east Germany after the country's reunification break the conservative mould of west German science. "Nothing is innovative now," comments Eigen.

Hilgenfeld denies allegations of scientific mediocrity, claiming that the atmosphere at the institute, and the quality of the scientific output, have "dramatically improved" since 1997. Hilgenfeld says he appreciates the "great contribution" of the first generation of scientists at the IMB - including Löber. But he is "sad that some of them are trying to run the IMB down as soon as they retire".

He says it was necessary to take a legal move against Löber to protect the IMB's reputation. He was worried that Löber's "campaign" had been launched in a bid to influence the institute's evaluation next month by

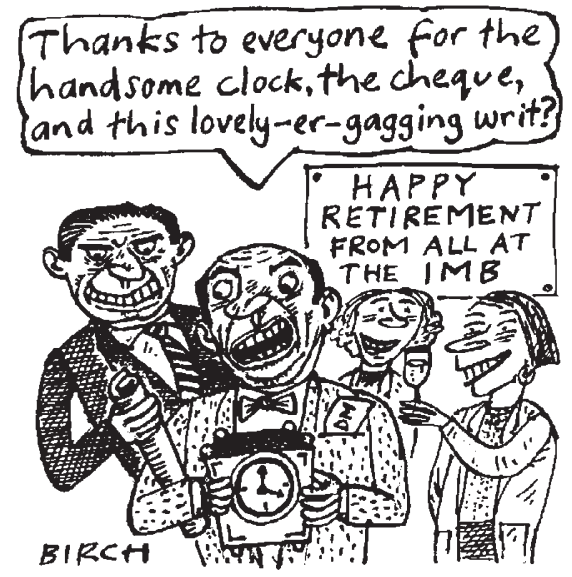

Germany's science council, the Wissenschaftsrat. He also points out that Löber immediately agreed to the injunction and willingly agreed to pay half the legal costs.

Löber says he was not planning a prolonged campaign, which was one reason why he was prepared to agree not to make further criticisms in public. But Peter Schuster, a former research director at the IMB who left during one of the disputes, sees the step to silence Löber as more harmful to the institute than Löber's public comments. "It is scandalous, and bad for the image of science," he says. Quirin Schiermeier \& Alison Abbott

\section{Laser project 'faces optics hurdle'}

\section{Washington}

The Lawrence Livermore National Laboratory in California has changed the top three managers of the National Ignition Facility (NIF), a $\$ 1.2$ billion laser project under construction there, and is reviewing the project to determine the full extent of its difficulties.

The US Department of Energy (DoE), which owns the lab, has said that one issue the need for clean-room conditions in the laser assembly area - accounts for most of the cost overruns on the project, which it admitted this month ran to hundreds of millions of dollars (see Nature 401, 101; 1999).

But some observers say that the project is dogged with other, harder technical problems, including difficulties in manufacturing several thousand large, precision optical components for its 192 laser beams.

Last week, Livermore officials were unavailable to discuss the optics or the cleanroom issues. But they are expected to do so after an initial project review by the new management team.

The clean-room issue came to light after Ed Moses, then head of another laser project at the laboratory, began an internal study of the laser assembly plans in January. By April he had concluded that the existing plan would not provide a clean enough environment.

Since then, project officials have been arguing about what to do, with Moses consulting outside experts, including engineers from Intel, the microchip manufacturer.

As this argument raged in June, both Bruce Tarter, the laboratory's director, and Bill Richardson, the energy secretary, were stating in public that the project was on time and within budget. The argument only became public after Mike Campbell, the laboratory's associate director for lasers, resigned on 27 August, ostensibly because he had not told the lab that he never completed his PhD.

As Campbell quit, Tri Valley Care, a laboratory watchdog group, told reporters and senior government officials in Washington that the NIF was up to $\$ 300$ million over budget. Richardson confirmed this within days, blaming the lab, and announced that an outside contractor would be brought in to ensure clean-room conditions during NIF assembly. Two other top NIF managers were replaced, and Moses took over as NIF project manager.

But Tri Valley Care claims that Campbell's resignation and the clean-room issue are a smokescreen that masks deeper 


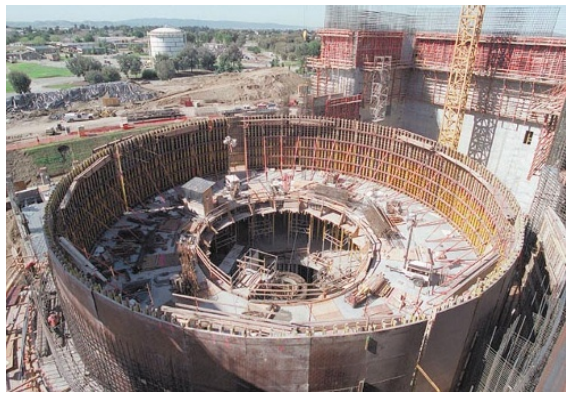

Time to come clean: critics say that the NIF's troubles go beyond clean-room difficulties.

problems. The watchdog group says its information comes from Livermore scientists worried about how the problems with the NIF are eating into other research budgets.

"The cleanliness problem is by no means the only problem," says Marylia Kelley, president of Tri Valley Care. "Some lab staff are derisive about that being the only problem."

Kelley says the optics - especially the potassium dihydrogen phosphate crystals used to generate the lasers - cannot be produced to sufficient quality and have been failing under test. The NIF specification required rapid-growth crystallization, ten times faster than that used in previous laser projects, to produce these components at the right cost.

One senior NIF scientist, speaking in Washington last week, was optimistic that the optics will be working in time. But the Livermore lab refuses to discuss the issue, and the DoE's denials of these problems are less than complete. "All of my information is that it is the complexity of the laser infrastructure, and not the optics" that have caused the cost overruns, says an official who has been speaking for Richardson on the issue.

The House of Representatives Science Committee will probably ask the General Accounting Office to investigate the NIF. The new management team and a panel of outside experts to be assembled by Richardson will determine where the project goes next.

The DoE says that the problems will have no impact on planned NIF collaborations in weapons research with the United Kingdom and France, except insofar as they delay the project's completion.

But non-weapons scientists fear that the overruns will move the NIF towards weapons research at the expense of experiments into obtaining energy from inertial confinement fusion. "It has gradually been happening anyway," says Steve Dean of Fusion Power Associates, a fusion-energy lobby group.

Observers say that the new managers are primarily weapons people. Also, a reducedspecification NIF that fails to achieve ignition - a prospect which Livermore officials privately acknowledge - will be more useful to weapons scientists than to fusion-energy researchers, who need ignition to prove the potential worth of inertial confinement fusion as an energy source. Colin Macilwain

\section{France set to cut search for small extrasolar planets}

\section{Paris}

Only a few years after the discovery of giant, extrasolar planets, a proposed French mission to extend the search to smaller planets in 'habitable' orbits is at risk of being axed. The project (see Nature 400, 316-317; 1999) looks set to fall foul of cuts imposed on the national space agency CNES by the science ministry.

The main scientific goal of the proposed Corot space telescope, which was due for launch in 2002, is to use seismology to study the internal structure of stars other than the Sun. But, with the telescope designed to fix the same part of the sky for 150 days at a time, astronomers built into the mission a second goal - detecting extrasolar eclipses.

Observing such eclipses would yield the orbital period and size of any planets with precision, says Frederic Bonneau, head of the mission at CNES.

But the mission, costed at a modest FF350 million (US\$55 million), including launch costs, is considered the primary target for cuts worth FF200 million to be imposed on CNES next year. The agency's science programme committee plans an emergency meeting next week to discuss Corot's future.

One member of the panel says it is likely to confirm its support for the mission, with pressure to axe Corot coming from the science

ministry, which is keen to trim France's commitments to big science programmes, and national projects in particular.

The panel member adds that space agency officials are in discussions with the ministry to try to win a reprieve for the mission. Other options to be considered at next week's meeting of the committee include postponing Corot, trying to reduce its costs, and searching for partners.

David Hughes, an astrophysicist at the University of Sheffield in the United Kingdom, is sceptical of Corot's chances of detecting planets, arguing that extrasolar eclipses are rare, even when one is looking at 6,000 stars. By definition, an eclipse would also be irreproducible, he points out. But he agrees it is a worthwhile secondary scientific objective. "If there is a reduction in brightness of the star, the data will hit them in the face anyway."

But Hughes describes Corot's main scientific goal as "super science". He argues that solar seismology has revolutionized stellar science by allowing researchers to "probe in depth" into the interior of stars, yielding information on pressure and temperature.

Because Corot would take the technique to other stars for the first time, "it is one of these space missions that has to happen," says Hughes. "If the French don't do it first, someone else will."

Declan Butler

\section{Call for UK biotechnology centre}

Sheffield

Britain's biotechnology industry last week called for the creation of a National Biotechnology Centre to boost confidence in its activities. In a report based on the findings of a government-funded delegation to the United States, the BioIndustry Association asked the government to create a centre to encourage and coordinate investment in biotechnology.

The report says that the US biotechnology industry has been encouraged by a supportive regulatory and planning environment, a responsive academic community and financial incentives.

The suggestion has already been backed by Sir Richard Sykes, chairman of Glaxo Wellcome and president of the British Association for the Advancement of Science. Speaking at the opening of the association's annual conference in Sheffield on Monday (13 September), Sykes said that such a centre was needed "if we are not to fall further behind the USA or be caught by Germany".

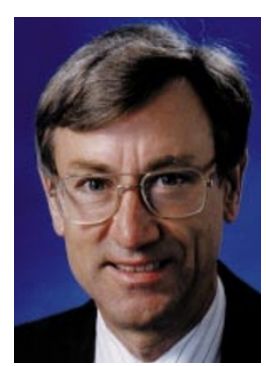

Sykes: looking for government backing.

"The Wellcome Trust is consequently looking elsewhere, including overseas, to find alternative suitable sites," he said. "A chance to create the infrastructure for exploiting our leading-edge science may have been missed."

Sykes added that Britain had fallen behind in the struggle to compete with developed and some developing countries. He said it was up to the government to create the right climate for Britain to prosper through science. 